Article

\title{
EU Smart City Lighthouse Projects between Top-Down Strategies and Local Legitimation: The Case of Hamburg
}

\author{
Katharina Lange * and Jörg Knieling \\ Institute of Urban Planning and Regional Development, HafenCity University Hamburg, 20457 Hamburg, Germany; E-Mails: \\ lange.katharina2@gmail.com (K.L.), joerg.knieling@hcu-hamburg.de (J.K.) \\ * Corresponding author
}

Submitted: 1 October 2019 | Accepted: 28 January 2020 | Published: 13 March 2020

\begin{abstract}
The concept of the smart city has become increasingly popular in recent years and a large number of cities globally follow smart city strategies. By awarding subsidies in the Horizon 2020 programme, the European Union (EU) has taken on an influential role in how smart city projects are conceived and implemented in European municipalities. Using the example of the smart city pilot project mySMARTLife in Hamburg, the purpose of this article is to examine the area of tension between strategically pursuing own objectives and adjustment to external provisions of the EU funding framework. In a qualitative single case study, the article analyses what implications the project mySMARTLife has on urban development practice and local governance arrangements in Hamburg. Examining current literature on smart cities from the perspective of multi-level governance and presenting the current state of research dealing with EU smart city projects, a theoretical framework is developed. The analysis reveals that, due to the EU funding framework, precise project contents are contractually defined at an early stage when local stakeholders have limited involvement in this process. Furthermore, the analysis shows that the EU smart city funding in the project mySMARTLife is more limited to the implementation of individual interventions than to a comprehensive smart city strategy. As a result, this article considers EU-funded smart city initiatives as experimental fields that enable cities to gain experiences that can be incorporated into local strategic development objectives.
\end{abstract}

\section{Keywords}

EU funding; governance; Hamburg; smart city; strategic urban planning; urban transition

\section{Issue}

This article is part of the issue "Urban Planning and the Smart City: Projects, Practices and Politics" edited by Andrew Karvonen (KTH Royal Institute of Technology, Sweden), Matthew Cook (Open University, UK) and Håvard Haarstad (University of Bergen, Norway).

(C) 2020 by the authors; licensee Cogitatio (Lisbon, Portugal). This article is licensed under a Creative Commons Attribution 4.0 International License (CC BY).

\section{Introduction}

In the last decade, the concept of the smart city has become extremely popular. More and more cities around the world have adopted smart city strategies or claim themselves to be smart. With the intention of simplifying local processes, enhancing sustainable development, or improving the quality of life for citizens, cities are implementing smart technologies and digital infrastructures (Alawadhi et al., 2012; Angelidou, 2014; Townsend,
2013). The concept of the smart city has long since ceased to be viewed only from a technological perspective. Holistic approaches on the topic comply with a more interdisciplinary dialogue and an increasing number of scientists from the field of urban research are examining the non-technical dimension of smart cities (e.g., Beretta, 2018; Desdemoustier, Grutzen, Cools, \& Teller, 2019; Engelbert, van Zoonen, \& Hirzalla, 2019). However, the idea of the smart city is still a fuzzy concept and cannot be defined in a consistent and common way as it is re- 
lated to different visions, objectives and individual strategies, and is highly dependent on the respective context (Dameri, Benevola, Veglianti, \& Li, 2019; Hollands, 2008; Vanolo, 2013).

In Europe, the vision of the smart city has been decisively influenced by the awarding of European Union (EU) subsidies for smart city initiatives. Seeking to reduce urban $\mathrm{CO}_{2}$ emissions and to improve the quality of life as well as the economic performance of European cities, the EU has been tendering calls for funding smart city projects within the framework of the Horizon 2020 programme for research and innovation (European Commission, 2016). Cities that were chosen to receive EU funding for a smart city project are designated with the prestigious title of a 'smart Lighthouse city.'

With the offer of the coveted subsidies, the EU is setting standards and definitions for smart cities. On the one hand, cities that have been awarded grants as Lighthouse cities in EU smart city projects get the chance to act strategically to benefit from the grant funds and to pursue its own interests and goals of development (Haarstad \& Wathne, 2018). On the other hand, grant recipient Lighthouse cities have to fulfil precise standards and targets regarding smart city development, adapt to the regulatory requirements of the EU and fulfil the agreed project framework. Thus, they bear the risk of following top-down development approaches with a lack of democratic legitimation and loss of municipal autonomy (Späth \& Knieling, 2018).

The City of Hamburg has adopted the aim to become a smart city and received the designation of smart Lighthouse city within the framework of the project mySMARTLife. In 2016, a local consortium began to transform the district of Hamburg-Bergedorf to a smart city following an applied and implementation-oriented approach. Using the example of the smart Lighthouse city of Hamburg, the purpose of this article is to examine the area of tension between the strategic pursuit of the city's own objectives on the one side and adjustments to and implementation of external provisions on the other side. The research objective is to discover how the city operates within this framework and which implications the project mySMARTLife has on urban planning practice and local governance arrangements in Hamburg.

Until now, little research has delved into practical smart city experiences and their implications on the local level (Mora, Bolici, \& Deakin, 2017), and the scientific community is encouraged to analyse "actually existing smart cities" (Shelton, Zook, \& Wiig, 2015) regarding their implications and expectations on the local level. In order to meet the research objective, the article examines the current literature on smart cities from the perspective of multi-level governance and the concept's implementation at the local level is presented. Further, the EU-funding framework in the Smart Cities and Communities Programme is outlined and the current state of research in this area is compiled. Based on the theoretical foundations, this article develops an an- alytical framework and applies it to the case of the City of Hamburg and the project mySMARTLife. Knowledge and empirical findings for this purpose were collected in different ways: On the one hand, being part of the mySMARTLife consortium responsible for scientific accompanying research, the authors followed the project with an observing role during the first three years and participated in relevant work and project meetings. In this way, knowledge from the project's inside perspective could be gathered. On the other hand, in-depth interviews with five relevant project partners and the project management were conducted and evaluated. Moreover, relevant documents, such as the grant agreement and interim reports as well as the mySMARTLife website and brochures have been analysed to get a deeper understanding of the project and its logic.

\section{Smart Cities from a Multi-Level Governance Perspective}

In order to understand the formulation of smart city policies and the implications of their implementation at the local level, the concept of the smart city must be examined from a broad perspective. The complex policies that lie behind a smart city encompass conditions that go beyond the local level. At the same time, smart city policies require cooperation among new constellations of actors and institutions on the local level (Dameri et al., 2019). In this regard, the multi-level governance perspective describes interdependencies and dispersed authority between different vertical levels of administration as well as horizontal relationships across different ranges of action (Bache \& Flinders, 2005).

Cities play a crucial role in the implementation of multinational agendas, such as climate action, sustainable development and the efficient use of resources (Bulkeley \& Betsill, 2005; Ehnert et al., 2018; Rohracher \& Späth, 2014). Such objectives are increasingly being pursued with the smart city approach. Accordingly, supranational organisations, such as the EU, have recognised the local scale as an important level of action and have compiled a common definition and strategic objectives regarding smart city development (Dameri et al., 2019; European Commission, 2017). Although the EU has no direct competence to act on urban policies, it tries to influence urban development indirectly through soft instruments, such as awarding subsidies for urban projects and supporting networks and knowledge transfer (Haarstad, 2016). This is also the case in the smart city field, where funding programmes are tendered, and networking and exchange platforms are promoted. In this way, policy intentions formulated on the higher level can induce and stimulate horizontal dynamics at lower levels, which can be seen as a form of multi-level reinforcement (Jänicke, 2015).

Private sector interests that go beyond the local level can also influence smart city policies in municipalities. Smart city projects are often the result of strategic co- 
operation between multinational companies and local authorities. While companies see cities as sales markets for their products (Viitanen \& Kingston, 2014), the aim of local actors is to implement technologies tailored to local needs and, thus, benefit from them (Caragliu \& del Bo, 2019).

As outlined, certain framework conditions of smart city policies are formulated on higher, exurban levels, influencing municipal decisions. However, the local level plays a decisive role in the final implementation of a smart city concept on-site (Dameri et al., 2019). Municipalities can benefit from the blurriness of the smart city definition and interpret the concept autonomously according to their own requirements and aspirations (Haarstad \& Wathne, 2018). The horizontal governance level of smart cities is characterised by the involvement of relevant stakeholders and institutions as well as new forms of collaboration between the involved entities. Also, the management of local human capital and knowledge production, as well as the participation of citizens, play a decisive role in styles of smart city governance (Caragliu, del Bo, \& Nijkamp, 2011; Meijer \& Rodríguez Bolívar, 2015; Nam \& Pardo, 2011). The interaction of these components at the local level can be regarded as particularly decisive for the character and success of a smart city initiative.

Municipalities with smart city objectives, therefore, make use of a global concept and are to some extent dependent on the definition and expectations of external competition for funding or investors regarding their strategy development, while, at the same time, cities tailor their individual smart city approach to their local context to tackle local challenges and specific needs (Angelidou, 2014). Since cities are extremely heterogeneous, smart city models and smart technologies can hardly be applied universally and equally to individual urban spaces. Thus, local smart city activities are always interconnected with existing social and spatial features (Karvonen, Cugurullo, \& Caprotti, 2018; Shelton et al., 2015). As a result, Dameri et al. (2019) consider the smart city as a glocal phenomenon, as it is affected both by global and local environments.

\section{Smart City Funding by the European Union}

Since 2014, the EU has funded a total of 15 projects involving 42 Lighthouse cities that are facing diverse challenges, such as ensuring secure, affordable and clean energy, supporting smart electro-mobility and implementing ICT supported solutions (EU Smart Cities, 2019). This section gives an overview of the background and objectives of the EU funding of smart city projects across Europe in the framework programme for research and innovation Horizon 2020.

With the Horizon 2020 framework programme for research and innovation, which implements researchdriven innovation within the framework of the Europe 2020 Strategy, the EU awards funding for smart city pilot projects. Aiming to enhance the EU's competitiveness on a global level, the Horizon 2020 programme focuses on promoting competitive research that supports growth, innovation-in particular so-called key technologiesand the generation of new business models (Horizon 2020, 2019). In this regard, the EU assigns an important role to cities regarding the transformation of energy systems and in meeting socio-economic challenges in Europe (European Commission, 2017). As a funding body, the EU has a specific vision of smart cities for its promotional purposes. Putting the focus on energy policies for smart cites, funded projects should aim to reduce greenhouse gas emissions through the increased use of renewable energy, improved energy efficiency in the building sector and the implementation of innovative transport systems (Vanolo, 2016). Moreover, the development of cities towards smart cities is primarily seen in connection with the use of innovative technologies and the development and innovation potentials (European Commission, 2017).

Funding calls in the area of Smart Cities and Communities have been advertised, asking for project applications from consortia consisting of different European cities and respective public and private partners. The tenders are designed to facilitate the cooperation of cities, industry and citizens to demonstrate solutions on a district scale, which are cost-effective as well as replicable at the intersection of energy, mobility and ICT (European Commission, 2016). Cities chosen to receive EU funding for a smart city pilot project are given the prestigious label of a 'smart Lighthouse city.'

Cities and project consortia that aim to design a successful project proposal must adopt this vision, corresponding objectives and regulatory requirements. Two parties of interest are thus present in this dynamic. On the one hand, the funding body-in this case the EUawards funding to city consortia that are obliged to implement a smart city initiative according to criteria stipulated within the grant agreement. On the other hand, cities have the interest to push forward their own development objectives and to implement these through external financing. In order to successfully apply for funding, certain local development objectives have to be adapted to the specifications, goals and smart city vision of the Horizon 2020 programme.

\section{EU Smart Cities: State of Research}

As there has not been a national funding programme in Germany for smart city initiatives until recently, the EU Horizon 2020 funding for smart city pilot projects has taken up a driving role in setting priorities for the conception of smart city initiatives. In this context one can argue that the vision of becoming a smart city has been institutionalised in Europe through the competition for EU funding (Dameri et al., 2019; Engelbert et al., 2019; Späth \& Knieling, 2018). Even if smart city projects are carried out autonomously on the local level, they can be 
seen as "a subset of a larger, supranational objective defined by the EU authorities" (Dameri et al., 2019, p. 36). Consequently, it is expected that funding from the EU Horizon 2020 programme has a considerable influence on the development of smart city concepts in European cities and a number of research projects dealing with the allocation of EU smart city funding and its implication have recently been conducted.

With regard to the vision of smart cities transmitted through the Horizon 2020 programme, Beretta (2018) criticises the EU's belief in technology. Beretta maintains that the EU sees modern technologies, implemented within the smart city concept, as a solution for most urban challenges without considering critical aspects, such as a lack of social inclusiveness and possible threats to democratic structures.

Späth and Knieling (2018) see the risk that smart city projects that are implemented on the basis of the grant agreement with the EU might follow a top-down approach and possibly have a lack of democratic legitimacy on the ground. Engelbert et al. (2019) take a similar view: They criticise the fact that the perspective of citizens in EU-funded smart city projects is not sufficiently taken into account. Moreover, they claim that there are hardly any participation activities with an open outcome. The idea of the EU smart city is critically described as too management-orientated and entrepreneurial, rather than tailored to the needs of citizens. Bauriedl (2018) focuses on urban living labs as a common approach of testing the implementation of technological solutions within smart city pilot projects and criticises this format in several ways: It is claimed that the tendency of standardisation of urban development processes in such living labs does not comply with the complex social reality in cities. Moreover, solution and management-oriented approaches of setting smart city initiatives into practice tend to lead to selective research and a lack of alternative approaches and views (Bauriedl, 2018).

Haarstad and Wathne (2018) try to broaden this perspective and the views on preliminary critical studies. They claim that cities can, on the one hand, function as passive recipients of smart city projects but also, on the other hand, have the chance to play an active role in strategically taking advantage of EU grants for pursuing own interests. Instead of focusing on possible top-down mechanisms that might arise to some extent from the funding relationship with the EU, they propose to consider smart city projects as "assemblages of local and trans-local resources" (Haarstad \& Wathne, 2018, p. 113). Further, the authors emphasise that cities benefit from the possibility to interpret the far-reaching smart city concept for themselves. In this way, cities can strategically allocate financial resources for the implementation of their own objectives embedded in the wide range of smart city measures.

Overall, the current research underlines that the smart city concept includes tensions that arise from the mainly innovation and technology-driven impetus on the one hand, and critical reflections on the impact of such an approach on the local democracy on the other hand. In addition to questions of how to organise innovation and motivate transformation pioneers in an intelligent way, broader discussions are opened about technological selectivity, social exclusiveness, legitimised decisionmaking processes and public participation of smart city strategies and related project-based concepts.

\section{The Project mySMARTLife in Hamburg}

In 2016, the City of Hamburg was awarded the status of an EU Lighthouse city in the framework of the project mySMARTLife. Together with Hamburg, the cities of Helsinki and Nantes also take part in the mySMARTLife project as Lighthouse cities, and the cities of Palencia (Spain), Rijeka (Croatia) and Bydgoszcz (Poland) have the role of 'follower cities.' The Lighthouse cities deploy a variety of different 'smart solutions' in the form of specific interventions that aim to reduce $\mathrm{CO}_{2}$ emissions, promote the use of sustainable energy resources and mobility and raise the quality of life for citizens.

In Hamburg, the demonstration area of mySMARTLife is located in Bergedorf, a district with about 130,000 inhabitants. The project consortium in Hamburg has twelve partners in total, comprised of authorities, research institutions and private partners.

The specific smart interventions that are carried out in Hamburg-Bergedorf encompass four different thematic fields. In the field of mobility, the project promotes e-mobility (the purchase of electronic busses, cars and bikes). Moreover, the charging infrastructure will be expanded and new offers for car-sharing established. In the energy sector, mySMARTLife aims to foster energysaving renovations of old buildings, the construction of innovative buildings with renewable energy and heating supply, as well as the implementation of smart home systems, smart metering and intelligent streetlights. In the ICT sector, the project focuses on the extension of the existing Hamburg-wide urban data platform and the connection with further data systems. These fields relate primarily to the implementation of innovative technical solutions at the district level. In the field of communication, mySMARTLife anticipates the implementation of engagement strategies for citizens and stakeholders as well as public relations work to foster the project's visibility and social acceptance.

\section{Discussion}

\subsection{The EU Smart City Lighthouse: mySMARTLife between Top-Down Strategies and Local Legitimation}

After outlining the relevant background knowledge, the following discussion explicitly addresses the research objective to reveal the area of tension that has arisen in the City of Hamburg with the application and permission of grants for the smart city initiative mySMARTLife. The dis- 
cussion illustrates how Hamburg, on the one hand, uses project funding to advance its own development towards digitisation and $\mathrm{CO}_{2}$ reduction and, on the other hand, operates in a competitive environment and adapts to the grant requirements of the EU. For this purpose, the complex governance structure the project is based on is examined using four categories: institutional embedding, smart city approach, actors and network and role of citizens.

\subsection{Institutional Embedding}

Regarding the administrative sector, Hamburg has a special role as both a city and a federal state. This implies that central public bodies have the responsibilities of a federal state, while the district's public bodies are in some way comparable to the municipal level. In Hamburg, the Office for IT and Digitisation within the Senate Chancellery is responsible for the citywide digital transformation. Thus, Hamburg's initiative to apply for grants within the Horizon 2020 smart city call also originated from the Senate Chancellery's office for international cooperation due to the mayor's priority on the topic of the smart city. After two earlier applications, Hamburg succeeded in the third attempt with its application for the Smart City Lighthouse project mySMARTLife in 2016. In order to increase the success of the application, external consultancies were engaged for the preparation of the project proposal. Thus, according to the District Office Bergedorf, responsible officials from the Senate Chancellery formulated the project contents with the support of external consultants and scientific institutions, while the district administration in Bergedorf was hardly involved at this stage of the process (District Office Bergedorf, Interview, 2018).

From a multi-level governance perspective, this is a very relevant point: Although the district government and administration are responsible for urban development issues, the project was primarily formulated at a higher administrative level. However, the subsequent responsibility for the implementation of the project lies with the district administration of Bergedorf, where a new administrative department was established to coordinate the project-related smart city activities. Due to the fact that mySMARTLife had been initiated from the administrative level above, initial tensions had risen on the part of the Bergedorf district authorities who felt ignored in the process of application and strategy development.

\subsection{Smart City Approach}

MySMARTLife is a demonstration project designed to test the implementation of new technologies in a mode of on-site experimentation (Bauriedl, 2018; Späth \& Knieling, 2018). Such approaches are becoming increasingly common in smart city projects and can be assigned to the concept of urban experimentation (Evans, Karvonen, \& Raven, 2016). An essential feature of ur- ban experiments is "a plan giving comprehensive instruction about what has to be built, how, where and when" (Cugurullo, 2018, p. 77). In the case of mysMARTLife, the grant agreement between the EU and the City of Hamburg and the project partners as contractors, constitutes the basis for the implementation of mySMARTLife project in the District of Bergedorf. It precisely describes objectives, interventions and responsibilities for putting the project actions into practice. Consequently, from a spatial point of view, major parts of the project are limited only to the demonstration area in the District of Bergedorf. From a temporal point of view, mySMARTLife objectives are limited to the project duration. However, according to the District Office Bergedorf, there is no clear overall strategy for the consolidation and continuation of achieved developments in the long run (District Office Bergedorf, Interview, 2018). Instead of a fundamental deep transformation towards the smart city, in which binding policies and institutional changes are implemented in the district (Meijer \& Rodríguez Bolívar, 2015), the mySMARTLife project is restricted to enabling the testing of individual technological solutions. Cugurullo (2018) criticises such urban experiments, as the individual fragmented measures are usually not connected across an overall concept and are therefore unable to achieve sustainable development on a larger scale.

However, the City of Hamburg aims to benefit in various ways from the sectoral and very precise practical experience gained in Bergedorf. The Senate Chancellery of Hamburg states that mySMARTLife experiences are to be transferred to other districts. Also, according to a respondent at the Senate Chancellery Hamburg, experiences will be incorporated into the political framework conditions for the entire city's digitisation and climate protection policy (Senate Chancellery, Interview, 2019). Overall, Hamburg's intention is to use external funding to implement a smart city project in accordance with EU guidelines and to incorporate the experience gained into its own strategies. This perspective is also supported by Frantzeskaki, van Steenbergen, and Stedmann (2018). The authors doubt that projects of urban experimentation could lead to transition but rather constitute a process of raising awareness how transformative change can be reached.

During the first years of the project, the strong dependency on the grant agreement has led to several challenges for the implementation of project interventions for the district authority. As the project was already conceived in the application phase a few years previously, some framework conditions have changed significantly, which make the implementation of some actions more difficult. These included economic conditions such as the low gas prices and legal changes such as a lower feed-in tariff for renewable energy from photovoltaic systems. Instead of being able to react flexibly to the current framework conditions, says a mySMARTLife partner, the project management in Hamburg had to ap- 
ply for complicated contract changes with the EU in several lengthy amendment procedures (mySMARTLife partner, Interview, 2019). This illustrates the control bias of top down grants awarded by the EU. To guarantee correct spending of public money, the EU administration has set up a strict financial control system dedicated to detailed implementation indicators in the grant agreement. However, this lacks flexibility for adapting to local processes and changing framework conditions, which cannot be foreseen in detail several years ahead.

\subsection{Actors and Networks}

The compilation of local partners for the project consortium took place in accordance with the needs of the project covering the fields of energy, mobility, ICT and public participation. The local partners were chosen according to prior existing local connections and networks from earlier collaborations. In the selection process, it was also ensured that the content of all prescribed sectors was covered by the partners. The project partners represent authorities, research institutions and private companies (District Office Bergedorf, Interview, 2018). Bauriedl (2018) characterises such a project consortium of partners as a discourse coalition. This refers to a group of actors who are linked by a constructed storyline and give equal importance to complex social circumstances over a certain period of time. The associated actors attempt to assert their shared view of social reality on others and use it as a basis on which decisions are made (Hajer, 1993). This can happen "through debate and persuasion, but also through manipulation and exercise of power" (Hajer, 1993, p. 45).

Within the consortium, the responsibilities and tasks of the individual partners are contractually regulated with the EU. Since it is very complicated to include further partners in the project afterwards, the consortium with the key actors of mySMARTLife forms an exclusive network. During the implementation of the project, this has proved to be a difficulty in Hamburg, as in the course of the project further important partners have been identified who would have made an important contribution to the success of some interventions. According to a mysMARTLife partner, there were also difficulties, as many services had to be tendered publicly according to the public procurement regulations, and contracts could not be awarded to the project partners without further efforts (mySMARTLife partner, Interview, 2019). Here it becomes clear again which challenges the rigid and barely flexible project structure entails in the implementation of the project into practice. For the private enterprises, this limits the attractiveness to collaborate in such consortia and to bring in their knowledge. In the worst case they invest a lot in the phase of project development but lose the tender to a competitor who did not have to invest any development costs at all.

In order to share experiences gained in the project with further stakeholders in Bergedorf as well as with other district administrations and specialist authorities in Hamburg, existing coordination formats have been used and additional informal networks and exchange meetings have been established. The newly created networks aim to promote exchange between stakeholders and to provide a forum for the discussion of issues, such as innovation, digitisation and energy transformation. According to the District Office Bergedorf, the new networks can be seen as a valuable asset from which Hamburg can benefit in the long term (District Office Bergedorf, Interview, 2018).

Due do the networks between authorities, the first impulses of mySMARTLife have been discussed in broader contexts in Hamburg. This can be seen in the example of the energy assessment of new zoning plans for settlement development. From the project's experiences, the idea was discussed to consider possibilities of a sustainable energy supply in the planning process. This correlated with the Hamburg Ministry for the Environment's engagement to adopt a new regulation for zoning, which includes energy assessment of new zoning plans and is binding for planning processes in Hamburg (District Office Bergedorf, Interview, 2018).

\subsection{Role of Citizens}

The project mySMARTLife in Hamburg considers itself as a project in which citizens play a central role. In this context, the mySMARTLife website contains statements and project descriptions such as:

Activities are focusing on "inclusive cities," offering a high quality of life to residents. "Smart People" are playing a vital role in their city's development....An integrated planning process, where citizens are actively involved in the decision making, links the actions in different fields (e.g., mobility, sustainable energy, ICT). (mySMARTLife, n.d.)

However, interviews with project partners as well as observations of the authors indicate that this external presentation of the project has not completely been fulfilled in the project practice. Regarding the role of the citizens of Hamburg-Bergedorf in the project mySMARTLife, the grant agreement plays an important role again. A project partner criticises that since the project contents and the procedure had been already precisely defined during the application, there was no longer any possibility to carry out participation procedures and to incorporate the concerns of the citizens afterwards into the smart city development of the District of Hamburg-Bergedorf (mySMARTLife partner 2, Interview, 2019). Overall, the impression is conveyed that this way of proceeding in the project has the character of a rather technocratic topdown approach that does not consider the perspective of citizens in an appropriate way.

While the project partners concentrate on the implementation of the interventions, possible negative so- 
cial effects on citizens in Hamburg-Bergedorf are hardly dealt with. In this regard, a project partner states that, for example, increasing rents through energetic or infrastructural upgrading would have been an important topic to consider-especially as the project names the promotion of inclusive cities as a goal. Instead of offering open-ended participation procedures, the information campaigns of the project have been more focused on seeking to create awareness and acceptance for the project goals and measures that had already been defined (mySMARTLife partner 2, Interview, 2019).

Looking at the role that citizens play in the mySMARTLife project in Hamburg, it can be summarised that the external framework conditions and specifications of the project dominate in this area and that only a little attention has been paid to the actual concerns of local citizens. This assumption can be underlined by the findings of Shelton and Lodato (2019). The authors critically note that current discourses on smart citizens hardly coincide with how smart city initiatives are implemented in practice and state that citizens at most play a peripheral role regarding power and decision-making. Also, Engelbert et al. (2019) criticise that the perspective of citizens is often neglected in smart city projects.

\section{Conclusion}

This article picked up the discourse of grant allocation as an instrument for smart city development and gave an insight into an actually existing smart city initiative and its implications on the local level. It was assumed that cities that receive EU funding for a smart city project have to operate in a field of tension between competing for the funding and adopting the external provisions on the one hand and aiming to use the grant strategically to pursue own objectives on the other hand. Using the example of the project mySMARTLife in Hamburg, the preceding analysis could confirm this assumption and reveals how the city acts in the framework of EU funding.

The successful acquisition of EU funding offers the City of Hamburg the opportunity to implement innovative and ambitious interventions in the field of digital and sustainable urban development in an experimental way. The analysis shows that the external influence of EU requirements is particularly noticeable in the way the smart city project has been developed and implemented. This is mainly due to the competitive procedure of applying for the grant, on the one hand, and to the rigid grant agreement that forms the contract between the EU and the project partners, on the other hand. As it precisely formulates the content and responsibilities of the project in detail, it offers very little flexibility to adapt to changing local conditions. This seems to be particularly problematic in the complex and rapidly changing environment of innovative technologies and poses many challenges to the project implementation.

A binding contract, which obliges to implement certain interventions without further involving citizens and other local stakeholders in decision-making, represents a rather old-school approach of top-down planning in urban development and there is a risk that cities will be curtailed in their autonomy of self-administration. In this regard, a more flexible funding framework would allow a more dynamic project implementation and cities could better incorporate the smart strategies within their local planning context and better involve citizens. Likewise, this could contribute to the democratic legitimacy of projects on the local level.

In the case of Hamburg as a city-state, it is also apparent that administrative responsibilities have shifted in the context of mySMARTLife, as the local level (district level) was hardly involved during the process of conceiving the project. At this point, cities should be cautious not to undermine the responsibilities and powers of action of the individual administrative and political levels.

Further, the analysis shows that smart city initiatives of this kind rather consider an experimental test field for the implementation of smart technologies than a deeper transformation to a smart city. In the case of Hamburg, the city tries to use these experiences, which would not have been gained without the project funding, and to pass them on to other districts or rather incorporate them into local strategic development objectives. As EU smart city initiatives are limited in space and time, the influence of the EU level through project requirements mainly relates to the setting in which cities test and evaluate innovative approaches and technologies. Against this background, EU funding could well concentrate on providing a creative environment for innovation instead of the described rigid steering approach. The success of the good practices will enhance the further development incrementally by being mainstreamed into local policies. Further research should explore more explicitly the structures and processes of how experimental approaches using the methodology of living labs etc. are connected with mainstream urban development policy and which obstacles and restrictions hinder the diffusion of such experiments. Then, the impact of single experiments on the sustainability performance of a city would be worth to analyse to better understand the urban innovation system and how it can contribute to achieving the requested sustainability transition on the local scale.

Finally, this study has shown that, despite certain needs for adjustment, the EU funding in the field of smart cities opens many doors for cities that support the development towards a digital and sustainable city. However, the criticisms revealed in this study also show that the EU as a funding body should rethink and adapt some of the procedural framework conditions in the competition for funding and its following implementation. The case of mySMARTLife Hamburg offers detailed insights into urban processes that connect with the broader scientific discussion on smart cities and urban transformation in the field of digitisation. Further research should make use of the group of smart Lighthouse cities to evaluate the questions of multilevel-dependencies and demo- 
cratic legitimation of such approaches. This could contribute to a more reflective European innovation policy that is aware of the societal responsibilities of such developments and that integrates technological and societal innovation in a more appropriate way.

\section{Acknowledgments}

This study was conducted in the frame of the project mySMARTLife and has received funding from the European Union's Horizon 2020 Research and Innovation Programme, under grant agreement No. 731297.

\section{Conflict of Interests}

The authors declare no conflict of interests.

\section{References}

Alawadhi, S., Aldama-Nalda, A., Chourabi, H., Gil-Garcia, J. R., Leung, S., Mellouli, S., \& Walker, S. (2012). Building understanding of smart city initiatives. In $\mathrm{H}$. J. Scholl, M. Janssen, M. A. Wimmer, C. E. Moe, \& L. S. Flak (Eds.), Electronic government (pp. 40-53). Berlin: Springer.

Angelidou, M. (2014). Smart city policies: A spatial approach. Cities, 41, 3-11.

Bache, I., \& Flinders, M. (2005). Multi-level governance. Oxford: Oxford University Press.

Bauriedl, S. (2018). Smart City Experimente: Normierungseffekte in Reallaboren [Effects of standardisation in real-world laboratories]. In S. Bauriedl \& A. Strüver (Eds.), Smart city: Kritische Perspektiven auf die Digitalisierung in Städten [Smart city: Critical perspectives on digitisation in cities] (1st ed., pp. 75-85). Bielefeld: Transcript.

Beretta, I. (2018). The social effects of eco-innovations in Italian smart cities. Cities, 72, 115-121.

Bulkeley, H., \& Betsill, M. (2005). Rethinking sustainable cities: Multilevel governance and the 'urban' politics of climate change. Environmental Politics, 14, 42-63.

Caragliu, A., \& del Bo, C. (2019). Smart innovative cities: The impact of smart city policies on urban innovation. Technological Forecasting \& Social Change, 142, 373-383.

Caragliu, A., del Bo, C., \& Nijkamp, P. (2011). Smart cities in Europe. Journal of Urban Technology, 18(2), 65-82.

Cugurullo, F. (2018). Exposing smart cities and eco-cities: Frankenstein urbanism and the sustainability challenges of the experimental city. Environment and Planning A: Economy and Space, 50(1), 73-92.

Dameri, R. P., Benevola, C., Veglianti, E., \& Li, Y. (2019). Understanding smart cities as a glocal strategy: A comparison between Italy and China. Technological Forecasting \& Social Change, 142, 26-41.

Desdemoustier, J., Grutzen, N., Cools, M., \& Teller, J. (2019). Smart city appropriation by local actors: An instrument in the making. Cities, 92, 175-186.
Ehnert, F., Kern, F., Borgström, S., Gorissen, L., Maschmeyer, S., \& Egermann, M. (2018). Urban sustainability transitions in a context of multi-level governance: A comparison of four European states. Environmental Innovation and Societal Transitions, 26, 101-116.

Engelbert, J., van Zoonen, L., \& Hirzalla, F. (2019). Excluding citizens from the European smart city: The discourse of pursuing and granting smartness. Technological Forecasting \& Social Change, 142, 347-353.

EU Smart Cities. (2019). Smart cities and community Lighthouse projects. EU Smart Cities Info System. Retrieved from https://smartcities-infosystem.eu/scclighthouse-projects

European Commission. (2016). Horizon 2020: Work program 2016-2017. Brussels: European Commission. Retrieved from http://ec.europa.eu/research/ participants/data/ref/h2020/wp/2016_2017/main/ h2020-wp1617-intro_en.pdf

European Commission. (2017). The making of a smart city: Best practices across Europe. Brussels: European Commission. Retrieved from https://smartcitiesinfosystem.eu/sites/default/files/document/the_ making_of_a_smart_city_-_best_practices_across_ europe.pdf

Evans, J., Karvonen, A., \& Raven, R. (2016). The experimental city. London: Routledge.

Frantzeskaki, N., van Steenbergen, F., \& Stedmann, R. C. (2018). Sense of place and experimentation in urban sustainability transitions: The Resilience Lab in Carnisse, Rotterdam, The Netherlands. Sustainability Science, 13, 1045-1059.

Haarstad, H. (2016). Where are urban energy transitions governed? Conceptualizing the complex governance arrangements for low-carbon mobility in Europe. Cities, 54, 4-10.

Haarstad, H., \& Wathne, M. W. (2018). Smart cities as strategic actors. Insights from EU Lighthouse projects in Stavanger, Stockholm and Nottingham. In A. Karvonen, F. Cugurullo, \& F. Caprotti (Eds.), Inside smart cities. Place, politics and urban innovation (1st ed., pp. 102-115). London: Routledge.

Hajer, M. (1993). Discourse coalitions and the institutionalization of practice. The case of acid rain in Great Britain. In F. Fischer \& J. Forester (Eds.), The argumentative turn in policy analysis and planning (1st ed., pp. 43-76). Durham, NC: Duke University Press.

Hollands, R. (2008). Will the real smart city please stand up? Intelligent, progressive or entrepreneurial? City, 12(3), 303-320.

Horizon 2020. (2019). Innovations in Horizon 2020. Horizon 2020. Retrieved from https://www.horizont 2020.de/einstieg-neuerungen.htm

Jänicke, M. (2015). Horizontal and vertical reinforcement in global climate governance. Energies, 8, 5782-5799.

Karvonen, A., Cugurullo, F., \& Caprotti, F. (2018). Introduction: Situating smart cities. In A. Karvonen, F. 
Cugurullo, \& F. Caprotti (Eds.), Inside smart cities. Place, politics and urban innovation (1st ed., pp. 102-115). London: Routledge.

Meijer, A., \& Rodríguez Bolívar, M. P. (2015). Governing the smart city: A review of literature on smart urban governance. International Review of Administrative Science, 82(2), 392-408.

Mora, L., Bolici, R., \& Deakin, M. (2017). The first two decades of smart-city research: A bibliometric analysis. Journal of Urban Technology, 24(1), 3-27.

mySMARTLife. (n.d.). What is mySMARTLife about? mySMARTLife. Retrieved from https://www.mysmartlife. eu/mysmartlife

Nam, T., \& Pardo, T. A. (2011). Conceptualizing smart city with dimensions of technology, people, and institutions. Paper presented at the 12th Conference on Digital Government Research, College Park, Maryland.

Rohracher, H., \& Späth, P. (2014). The interplay of urban energy policy and socio-technical transitions: The eco-cities of Graz and Freiburg in retrospect. Urban Studies, 51(7), 1415-1431.

Shelton, T., \& Lodato, T. (2019). Actually existing smart citizens: Expertise and (non) participation in the making of the smart city. City, 23(1), 35-52.

Shelton, T., Zook, M., \& Wiig, A. (2015). The 'actually ex- isting smart city.' Cambridge Journal of Regions, Economy and Society, 8(1), 13-25.

Späth, P., \& Knieling, J. (2018). Endlich Smart-CityLeuchtturm. Auswirkungen des EU-Projektes mySMARTLife auf die Planungspraxis in Hamburg [Finally Lighthouse-smart-city. Impacts of the EU project mySMARTLife on planning practice in Hamburg]. In S. Bauriedl \& A. Strüver (Eds.), Smart city: Kritische Perspektiven auf die Digitalisierung in Städten [Smart city: Critical perspectives on digitisation in cities] (1st ed., pp. 345-356). Bielefeld: Transcript.

Townsend, A. M. (2013). Smart cities: Big data, civic hackers, and the quest for a new utopia. New York, NY: W.W. Nortin \& Company.

Vanolo, A. (2013). Smartmentality: The smart city as disciplinary strategy. Urban Studies, 51(5), 883-898.

Vanolo, A. (2016). Is there anybody out there? The place and role of citizens in tomorrow's smart cities. Futures, 82, 26-36.

Viitanen, J., \& Kingston, R. (2014). Smart cities and green growth: Outsourcing democratic and environmental resilience to the global technology sector. Environment and Planning, 46, 803-819.

\section{About the Authors}
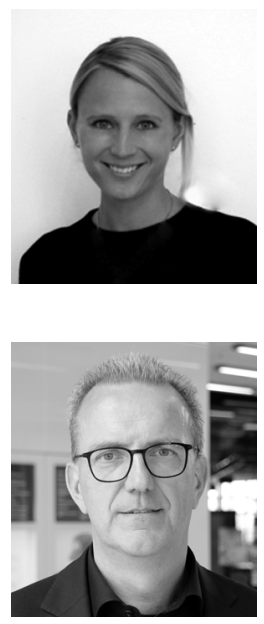

Katharina Lange was a Research Associate at the Institute of Urban Planning and Regional Development at HafenCity University Hamburg. She studied spatial planning and land-use planning at the Vienna University of Technology, the Royal Institute of Technology in Stockholm and the Technical University of Dortmund. Her research interests are in the field of smart city, transformative governance and sustainable urban development.

Jörg Knieling holds the Chair of Urban Planning and Regional Development at HCU and is Dean of HCU's Urban Planning Programme. He is a member of the German Academy for Spatial Research and Planning (ARL) and the Advisory Board for Spatial Development of the German Ministry of the Interior. His main research fields are sustainable urban and regional development, spatial development and climate change, and related aspects of territorial governance and planning theory. In recent years, he has conducted several international and national research projects; previous publications include Cities in Crisis (2016), Climate Adaptation Governance in Cities and Regions (2016), Soft Spaces in Europe (2015) and Planning Cultures in Europe (2009). He has been referee of the European Commission (DG Research), the European Institute of Technology (EIT) and national research councils throughout Europe. 